\title{
LARAS IN GAMELAN MUSIC'S PLURALITY
}

\author{
Widodo \\ $\square$ Music Department, Faculty of Languages and Art, Semarang State University, \\ Sekaran Gunungpati, Semarang 50229, Indonesia \\ E-mail: widodo_bsejati@yahoo.com
}

Received: April 22, 2015. Revised: May 5, 2015. Accepted: June 13, 2015

\begin{abstract}
Coercion, strife, contention, assault, and battle between individuals and groups today have never deserted from the news in mass media. The triggers are selfishness, feeling of self-righteous, overbearing, and a desire to be always comfortable and win, while neglecting differences had by one to another. It is pushed by unwillingness and inability to respect the differences as God's will and grace. Plurality as an inevitability cannot be ignored as well as rejected. Willy nilly, it has to be faced, accepted, and respected as it is. It also needs to be assembled in order to actualize harmony in togetherness as in diversity in the musical aspects of traditional Javanese karawitan in gending composition. This paper is a reflection result towards diversity in gending composition which raises beautiful musical alignment in order to reflect the plurality in life and to build harmony.
\end{abstract}

Keywords: laras; plurality; karawitan; gamelan

How to Cite: Widodo. (2015). Laras in Gamelan Music's Plurality. Harmonia: Journal of Arts Research And Education, 15(1), 34-45. doi:http://dx.doi.org/10.15294/harmonia.v15i1.3695

\section{INTRODUCTION}

Recently, willingness and ability to appreciate and respect differences are strongly decreasing. Coercion, strife, contention, assault, and the battle between individuals and groups which are triggered by the selfishness, self-righteous, overbearing, wants to be always comfortable and win, while neglecting differences with others have never deserted from the news in mass media. Dissatisfaction over the law decision can end in strife and dissension. Security officers who are supposed to create a safe state for the people, even shooting one another instead of securing society just because of a small problem. Students of formal education institution as the next nation generation are often involved in fights between groups. Groups of people on be- half of a particular belief seemed to be justified to attack another group and end up to have many casualties. Political nuances of particular religious ideology have become a covert movement that led to the imposition of the will towards homogeneity that refuses diversity. In addition to it, there are many other dreadful news that shows the spirit of hostility towards difference.

We need to take a look at the ancestral cultural heritage of the nation that has not completely disappeared from the records and memories. The ancestors had realized that diversity was natural reality given by God which was impossible to be rejected and avoided. Paku Buwana IV in the text of Tembang Pangkur Wulangreh said that:

Sekar Pangkur kang winarna Lelabuhan kang kanggo wong aurip 


\section{Ala lan becik puniku \\ Prayoga kawruhana \\ Adat waton punika dipun kadulu \\ Miwah ingkang tatakrama \\ Den kaesthi siyang ratri}

People as the superior human beings who have had thought and mind are having an obligation to angrawuhi or to understand differences, ala lan becik or bad and good, involving adat waton or human nature and habit with full manners in order to mamayu hayuning bawana, to maintain and enhance the degree of safety and beauty, and not to make excessive exploitation and even to destroy it.

The ancestors pass down adi luhung (wise) messages which are packaged in art works for us to respect diversity and create harmony. One of the artworks here is Javanese karawitan, the inherited traditional music of Java. From the point of view of materials, shapes, measurements, playing technique, nature and character, task, as well as musical function in Javanese karawitan, there are different ricikan and vocals. However, the difference is not creating disharmony. In fact, it creates a beautiful musical composition of Javanese karawitan which is well-known as laras. Learning from this Javanese karawitan, how beautiful it will be if every diversity aspect in this life is maintained in order to realize a beautiful and harmonious condition. This paper is an afterthought on how Javanese karawitan can be learned as the reflection of harmony in plurality. How is plurality in Javanese karawitan created in order to establish laras? This question will be briefly discussed in order to reveal and discover positive values in laras as the reflection sources in order to build harmony and diversity.

\section{PLURALITY IN JAVANESE KARAWI- TAN}

Plurality is derived from the word plural. It means more than one, compound, heterogenous (KBBI). A plurality means the situation where there are numerous people with much diversity, plu- ralism, and heterogeneous (Echols \& Shadily, 2010:435). Pluality is the reality of life. Millions of His creature are in different state. One of the type is human. Every human is different physically and psychically. Shape, measurement, skin colour, voice, walking style, talking style, hair type, and other physical aspects are different. For the non-physical aspects, such as: nature, desires, wants, needs, thoughts, beliefs, pleasures, abstinence, etc. are all different as well. Those differences are implicated to the diversity of human culture. Culture is a whole system of human ideas, actions, as well as art works which are obtained through the learning process. It is universally comprised of the aspects of language, knowledge system, social organization, technology, occupation, religion, as well as the arts. Each of the aspect is transformed into three forms of culture, there are (1) complexity of ideas and norms, (2) human activities, and also (3) human artefacts (Koentjaraningrat, 1980, p. 216).

Plurality is an inevitability in life. Therefore, whether it is agreed or not, the plurality has to be faced, accepted, and respected as it is. It is impossible for us to avoid or reject its existence. One way to maintain diversity is to build a country organization and form a governmental system which is open for participation from any parties in order to develop togetherness. Throughout the historical memory, there had never been a state or government was built without mankind's intervention. The appearance of Hindu or Buddhist religion in Nusantara (Indonesia and its colonization area) bequeathed a royal power system. In this region once stood Buddhist kingdom of Srivijaya and Majapahit Hin$\mathrm{du}$ as the first and the second Nusantara empire. The advent of Islam affected to the establishment of the kingdom of Demak and Mataram (Islam), and the presence of the European nation with the Christian gospel, built a system of the Dutch East Indies.

The collapse of Srivijaya provided lessons for Majapahit in maintaining its political sovereignty. Disintegration 
triggered by differences in beliefs, anticipated by uniting the differences. Hinduism allows for the slaughter of animals for ritual ceremonies, while the Buddha forbid it. Hindus believe that the Buddha is an avatar (incarnation) of Vishnu as Krishna Vasudeva, while the Buddha Dharma does not teach it. Hinduism teaches that the highest essence is the Atma, while the Buddha is without Aku (sabbe sangkhara anatta). Interestingly, although some aspects of the conflicting teachings, but bloodshed between community groups on behalf of Hindu and Buddhist had never been heard. Both also employ similarities in the teachings of certain aspects such as karma, that good works will reap the happiness and evil deeds will earn suffering. Both realized that the teachings of dharma can not be limited by the ability of human thought. People may differ in perceiving dharma, but there are no two conflicting truths. There is only one truth, which is the truth itself. Buddhist poet, Mpu Tantular, in his work entitled Negara Kertagama delivers a slogan Shiva-Buddha Bhinneka Tunggal Ika Tanhana Dharma Mangrwa, which means although Hindu and Buddhist are different, however, there are in one unity since there is no ambiguous truth.

Diversity in Nusantara today is legally recognized, however, its management has not yet fully capable of ensuring all components of the nation's independence in carrying out their respective belief. Reality shows that community groups on behalf of a particular belief is still free to do the will of the coercive action by violent means. They perform their action when they consider that they have found the appropriate momentum. This shows that acceptance, respect, and respect for the differences have not been fully internalized and implemented by all elements of the nation. Therefore, countries need to constantly maintain in order to ensure that all elements of diversity are truly free without threats, coercion, and violence. The values of tolerance, harmonious, respectful, mutual assistance, mad-sinamadan, daya-dinayan which are rooted in the national cul- ture should be developed in order to live together in a diversity can be lived in harmony like the beautiful knit of diversity in musical composition Javanese karawitan.

Martopangrawit in his writing entitled Pengetahuan Karawitan (the Knowledge of Karawitan) delivers that karawitan is the art of voice either vocal or instrumental which employs slendro and pelog laras (Widodo, 2010, p. 172). Karawitan is also known as Gamelan music. In Indonesia, the term Gamelan is used to address to a set of musical instruments (ricikan) which comprises ricikan of metal, wood, leather, wire or string, bamboo, or a mixture of two or three materials in either laras pelog or slendro. Whereas, karawitan refers to its musical and cultural system (Supanggah, 2002:12). The Gamelan was also previously known by mrdangga, which means kendang. The term was changed to merdangga, then mradangga, and finally pradangga. Another synonym is gangsa, it is an acronym of tembaga (copper) and rejasa (white tin) as the materials to make bronze. Bronze itself is well-known as the best metal to make a blade, pencon, disc, and the other ricikan which are made of metal. Ricikan Gamelan can also be made of iron and brass, however, the quality is far behind the bronze. The combination of final syllable temba$g a$ and rejasa, gasa, which is merged into gangsa, turns into another term for gamelan. Gasa also refers to the dose size composition of copper and rejasa. Further, the best comparison for the combination of copper and rejasa in order to make bronze as the material instrument of Gamelan is tiga-sedasa or three to ten. Three for the rejasa and ten for the chopper.

Material, type, shape, size, technique, play pattern, duties and musical functions of each ricikan Gamelan in Javanese karawitan are varied. Materials used to make Gamelan are: metal (bronze, iron, brass), wood, bamboo, leather, wire or string, as well as a combination between the previously mentioned materials. Metal made ricikan has various shape, there are: (1) pencon, it consists of two types: pencon wadon and pencon lanang, (2) wilah or bla- 
de, it comprises of three types: nggeger sapi blade, kruwingan or blimbingan, and nyigar penjalin; (3) piringan berpencu; (4) bladdery piringan without pincu; (5) ricikan which shaped like a banana. Nggeger Sapi is a type of blade which shaped like a cow's back, blimbingan is a type of blade in which the surface is shaped like a star fruit, while nyigar penjalin shaped like split rattan.

Reckon made of wood, skin, and also wire also has a variety of shape and size, such as: cylinder, wood shells, membranous bathokan, stringed box, as well as a hollow bamboo. The size of each ricikan are varied depending on its name and type.

Every ricikan gamelan explained above is grouped according to the needs. $\mathrm{Ga}-$ melan makers divided the racikan into two groups, pencon and wilah in order to ease the production process as well as to determine the mold, size, type, dose, and the amount of material required. Other ricikan which are made of non-metallic materials are not taken into account because the manufacturing is done by other artists. Grouping is also made according to the playing technique, namely: ricikan kosok or stringed instrument which is rebab, sebul or wind instrument which is suling, plucked instrument which are clempung and siter, kebuk or keplak which is kendang, and percussion instruments which are bonang penembung, bonang barung, bonang penerus, gendèr barung, gendèr penerus, slenthem, demung, saron, peking, kenong, kethuk, kempyang, kempul, gong, kemanak, kecèr, gambang, engkuk, kemong, as well as bedhug.

Ricikan Gamelan classification is also done on the basis of duties and musical functions of the gending (Javanese songs or sounds) performance. There are two types: ricikan pamurba or the leader and pamengku or supporter. The task of pamurba is to lead the gending, whereas pamengku is to frame and follow the musical ideas which are given by ricikan pamurba. There are two types of ricikan pamurba, which are song pamurba which is rebab and pamurba irama that is kendang. Other ricikan that are having the task to lead the song are bonang barung, gendèr barung, gendèr penerus, bonang ba- rung, bonang penerus, gambang, clempung, siter, suling, slentem, demung, saron, and saron penerus. Whereas, racikan that are having the task to support the ryhtym are kethuk, kempyang, kenong, kempul, gong, kecer, dan kemanak (Martapangrawit, 1975, p. 3). Classification on the basis of the ricikan position that is closely related to the roles and level of difficulties in gending presentation are: (1) ricikan ngajeng (front ricikan). It consists of rebab, gendèr barung, bonang barung, and pesindhèn; (2) middle ricikan which consists of slentem, demung, saron, saron penerus, gambang, kempul-gong, gérong, kenong, siter; (3) wingking or back ricikan that consists of bonang penerus, gendèr penerus, kethuk-kempyang, and suling. It needs to be noted that this classification is not the fix arrangement or rule. It means that a ricikan can be moved to another group according to the purpose of the karawitan presentation. In klenèngan, kempul and gong are often categorized into wingking (back) group, however, in shadow puppet show, it is usually categorized into middle group. Fees and respect for the music players are central in determining the grouping type.

Supanggah (2002, p. 71) formulates the classification of ricikan Gamelan based on the musical role in garap gending (the performance). They are: (1) ricikan balungan, a group of ricikan in which the presentation is closed to balungan gending, it comprises slentem, demung, saron, saron penerus, and bonang penembung; (2) ricikan garap, a group of ricikan which plays balungan gending by interpreting, selecting, and implementing the technique of certain céngkok or sekaran, and wilet based on the character and purpose of the gending presentation. Ricikan which belongs to this group are rebab, gender barung, gendèr penerus, bonang barung, bonang penerus, gambang, siter, clempung, suling, and vocal (sidhèn dan gérong); (3) structural ricikan, a group of ricikan which the playing patterns are determined or determining the gending form. It comprises kethuk, kenong, kempul, gong, engkuk, kemong, kemanak, and kecer.

The next is playing technique. The 
playing technique deals with how to produce the sound of ricikan. Ricikan playing techniques can be classified into two types, namely general and specific techniques. The general technique comprises the way to swipe, pluck, menggebuk or mengeplak (to beat the musical instrument hard), blew, and beat as well as the way to close it in order to get quality sound according to the character of each ricikan. Special techniques contained in certain ricikan, the group of ricikan balungan has both genjotan and kecekan techniques. In addition, rebab has ngicrik, kadhal menek, sendal pancing, and plurutan. While gendèr barung has the teachniques of gugukan, genukan, samparan, sarugan, pipilan, umbaran, pethetan, mbalung, ukelan, etc.

Furthermore, the playing pattern is also well-known as céngkok, sekaran, or kembangan. Almost all ricikan gamelan as its own playing pattern. The playing pattern in ricikan balungan are pinjalan, imbalan, cacahan, kintilan. In bonang barung, the playing pattern comprise milah, pipilan, gembyangan, klenangan, and imbal-sekaran. In gendèr barung are putut gelut, putut semedi, jarik kawung, kacaryan, ora butuh, gantungan, ayu kuning, ela-elo, dua lolo, tumurun, dhebyang-dhebyung, nduduk, rambatan, ya suraka, etc. The previous brief illustration merely shows that in terms of material, shape, size, technique, pattern games, duties and musical function, the ricikan gamelan in Javanese karawitan are very diverse. Such diversity is a unifier element of the alignment of musical compositions in Javanese karawitan musicality. The following shows the musical diversity of karawitan from garap gending (song arrangement) point of view.

Garap literally means to make or to do certain goods, rice fields, arithmetic, houses, and other construction materials (Perlman, 1993, p. 163). Conceptually, garap is a system of creative work which consists of several stages, each of which support each other to produce a particular result. Supanggah (2009:3-4) states that garap in Javanese karawitan employs several aspects, which are: (1) material, in a form of gending and balungan gending; (2) penggarap, they are pengrawit, pesinden, and wiraswara (the music player, the singer and backing vocal); (3) the tool or medium, in a form of gamelan instrument; (4) the devices, it is the technique and vocabulary mastery, comprises of céngkok, wiled, irama and laya, laras, pathêt, as well as dynamic; (5) determinant, it is signs which can affect garap, such as the authority, the social function as well as art services; (6) consideration, it is the accidental circumstanses which affect the presenter in deciding the garap, like the internal physical and psychological condition of presenters as well as the external condition, such as the audience and presentation purposes. Waridi (2000: 2 ) adds that the ruler, taste, money, functionality, forums, figure, environment, oral and communal nature can be a motivating factor in the emergence of alternative garap on Javanese karawitan.

This part will only show one element of garap in Javanese karawitan, which is gending. Gending or karawitan is the composition of material, object, or event to work on for the artists of Javanese karawitan to make it into a wonderful musical performance. Laras, rhythm and laya, the musical form (form of gending), and pathêt are the main aspects inside gending. It also needs to be known that each aspect has its own diversity aspect.

Laras in this context means tone and scale. As the scale, laras is a system of frequency setting and tone interval in $k a-$ rawitan. Laras containing a row of seven and five tones that form a circle, starting with a certain tone (basic) and ends with that very same tone in higher or lower gembyangan (octave). In gamelan, this system is divided into two: sléndro and pélog (Martopangrawit, 1975:5; Sutton, 1991:28; Hastanto, 2009:23; Kusnadi, 2006:111-113). Sléndro occupies five tones in one octave with the relatively same interval, more or less 240 cents (Hardjito, 2001). However, the numbers are not the standard size. It can be slightly reduced or increased. In the context of embat or the variety of interval structure (jangkah), in the tone and scale 
that determine the nature and characteristics of gamelan instrument, those numbers can be slightly reduced or increased. Although it has five tones formally, however, every tone in laras sléndro can be increased or decreased up to half tone or wilah.

Pélog comprises seven tones in one scale (gembyong). The names and symbols are panunggul (1), gulu (2), dhadha (3), pé$\log (4)$, lima (5), nem(6), and barang (7). The prononciation is the same as the tones in sléndro, which is to be pronounced ji, 2 ro, 3 lu, 4 pat, $5 \mathrm{ma}, 6 \mathrm{nem}$, and $7 \mathrm{pi}$. In particular, for 7 , it is not pronounced as $t u$ but pi under ethical and aesthetical consideration. The tone 7 in karawitan can be followed by the tone 5,6 , and 2 . If 7 is pronounced $t u$, therefore, the combination pronounciations are tu-ma, tu-nem, and tu-ro respectively. Tuma is actually the javanese word for lice while turo $(k)$ is women's vagina. Therefore, in order to not to create negative impression, the tone 7 is pronounced pi.

Rhythm or wirama in Javanese term is another important musical element in karawitan besides laras. Martapangrawit (1975:1) states that rhythm is widening and narrowing gatra (line) with multiple or two ratios. The presentation Javanese gending itself can be done in a gradual or terraced tempo which creates distance consequences which is well-known as widen sabetan balungan or vice versa, so that, some of ricikan in the group of garap have to fill the gap by playing the instruments in two beats. The slower of sabetan balungan is played as a result of tempo gradation, the gap is also wider, and vice versa. The gap has to be filled with ricikan played in two beats (Supangah, 2007:76).

Javanese karawitan has five gradations of rhythm (irama), there are: lancar, tanggung, dados, wiled, and rangkep. Martopangrawit (1975:1) identifies the gradations on the basis of the numbers of sound saron penerus in every sabetan balungan gending. The slower one sabetan balungan gending leading to the another sound of sabetan balungan gending, saron penerus has space and time to multiply its beat, and vice versa. If at any sabetan balungan, saron penerus is only "able" to play one beat, so that, the rhythm is called lancar $(1 / 1)$. If the total beat is twice in each play, it is called irama tanggung (1/2). Futher, if the total beat is four times in each play, it is called irama dadi/ dados (1/4). The last, if the total beat is eight times in each play, it is called irama wiled. In Javanese karawitan is also known irama rangkep, laya which is in certain irama is slowed. So that, in certain limitation, saron penerus keeps multiply its beat counts.

Most of Javanese karawitan musicians are often employed the term irama siji or I, irama loro or II, and irama telu or III. The substance of irama siji is equal to irama lancar and tanggung, irama loro is equal to irama dados and wilet, and irama telu is identical to rangkep. A certain irama is called siji if (started from the opening till the certain part of the music) it plays irama lancar to tanggung. It is called irama II if the music has already established (dados) and is placed in irama dados or wiled gradation. Lastly, if the rhythm is double, therefore, the gradation is called irama telu or III.

The term laya is borrowed from Indian music terminology to refer to the rhythm aspect which is closely related to the time or tempo of the gending (Supanggah, 2002, p. 127). Laya is the speed gending in the same rhythm gradation. Javanese $k a-$ rawitan do not have an exact tempo measurement as in western music, as for using the metaphor adante (motion), marche (line up), or second unit size and metronome. The speed of gending is determined by the speed of kendang. Javanese karawitan musician is usually called the tempo of gending with the specific tem tamban or alon, langsam, nglentreh for the slow tempo, sedheng or medium tempo, and seseg, cepet, or fast tempo.

Each kendang player has their own habit in playing the gending tempo. The tempo is varied. There are fast, medium, and slow. The tempo can be influenced by internal factor, like, the condition of emotion, character, and capacity of the player. There are also external factors, for instance, the atmosphere around the venue, time of presentation, and the request of 
the other parties. The unstable emotion of the kendang player can affect the tempo of kendang becomes unstable also, so does for the careless one, and if the kendang player is a newbie. The gending performance in a night fair tends to have fast tempo. It is different to the performance held in governmental place to the appreciation need. Request from the other parties to speed up or slow down the tempo of the musical performance has an obvious effect on the laya in gending performance.

Javanese karawitan musical compositions have a variety of forms. The meaning of shape in this case is similar to the shape in general music as well as language. Shape or the form of music is a set of tone that contains the rhythm, melody and structure. If the smallest unit of language is letter, then, the smallest unit of music is tone. The letters in the language arranged into words, words into phrases or sentences, sentences into paragraphs, and paragraphs into discourse, and the tone of the music arranged into patterns, motifs into phrases, phrases into a song. The letters in the language are arranged into words, words into phrases or sentences, sentences into paragraphs, and paragraphs into discourse, and the tones of the music are arranged into motifs, motifs into phrases, and phrases into a song. In Javanese karawitan, tones are arranged into gatra, gatra into kenongan, kenongan into gongan, and the arangement of gongan into gending. Kenongan is a song sentence which is ended by kenong, gongan, and gong.

The form of gending has its own format and name. The large format of gending is called gending ageng, the medium one is called gending sedheng, and the small one is called gending alit. Format size of the gending is determined by the amount of sabetan balungan in each gongan. The greater the number of sabetan balungan, therefore, the gending format is bigger, and vice versa. The gending form is also determined or determining the play pattern of the structural ricikan. The rhythm pattern of the song is characterizing the gending form. Some of the gending form in Javanese karawitan are:
(1) gending alit, as follows: sampak, srepeg, lancaran, gangsaran, ayak-ayak, kemuda, ketawang, ladrang, dan jineman; (2) gending sedheng, there are: ketawang-gending and gending kethuk 2 kerep; (3) gending ageng, it is kethuk 2 arang, kethuk 4 kerep, kethuk 4 arang, kethuk 8 kerep and kethuk 16 kerep; and (4) gending pamijen (Supanggah, 2009, p. 126).

The concept of pathêt in karawitan is interpreted variously by the experts, among them are as follows: (1) pathet as the theory of tone gong, (2) pathêt as the melody theme development; (3) pathêt as the combination of contour, tone and position; (4) pathêt as the concept which concepts that manage the duties and functions of the tone; (5) pathêt which is related to garap; and (6) pathêt which is an atmospheric sense of sèlèh. Either laras sléndro or pélog, each has gending or musical composition, which are: (1) laras sléndro, gending-gending pathêt nem, gending-gending pathêt sanga, and gending-gending pathêt manyura; and (2) laras pélog, which is gending-gending in pathêt lima, gending-gending in pathêt nem, bem, or nyamat, and gending-gending in pathêt barang. Gending-gending in laras slendro also have variants of pathêt which is called miring and is marked as garap miring. Rebab and vocal in certain parts of gending have to be increased a half wilah. Each pathêt in gending repertoar of either laras sléndro or pélog has different garap consequences.

\section{LARAS AS BEAUTIFUL SENSE}

Laras is a fundamental principle for Javanese people as a foundation and the intended direction in the act to achieve the perfect balance point. Javanese community uses it in the twelve context of usage implicitly and explicitly, there are: (1) laras in samadi or meditation; (2) laras in klenèngan murya laras and mahas ing raras; (3) laras in social intercommunication; (4) laras in ginem raras bawa raos; (5) laras in panglaras (moderator); (6) laras in nglaras, the beauty of nature and a relaxed art to loosen the nerve; (7) laras in nglaras rasa, a sense of inner processing to attain a higher degree of spiritual maturity; (8) laras as the name of a person, organization, and certain goods or 
belongings based on the concept of asma kinarya japa; (9) laras as the scale designation of sléndro dan pélog; (10) laras refers to tones in sléndro and pélog; (11) laras in nglaras gamelan, the laras manufacture or repair in gamelan; (12) laras in leres, rempeg, and laras as the parameter to measure the sense quality of karawitan which is developed in garap and gending performance.

Laras in this context means the type of sense, atmosphere, conditon, or impression of beauty which is deep and touching and is arised after accomplishing a perfect balance point in a "pull and push" interaction (Suharto, 1992, p. 20-31). The balance illustration can be see from the swing movement in children swing, that is the extreme position in the outer pole will create balance after it is released naturally. A pole will be strongly moving back to its origin if another side of the outer pole is swinging strongly, so that the distance from the axis is becoming further (Syafie, 2011: 3-4).

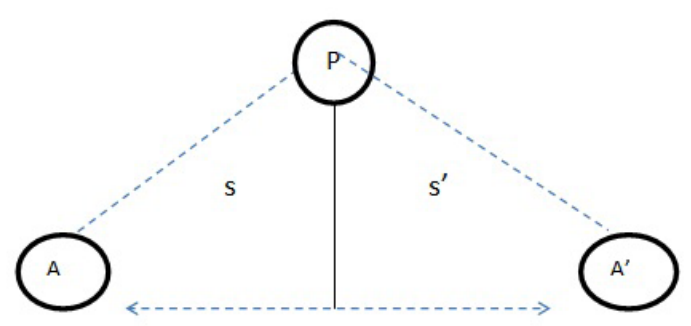

Figure 1. The illustration of balance in children's swing

Note:

P: Axis, A: The outer side of the pole $1, \mathrm{~A}^{\prime}$ : the outer side point 2 ,

$S$ : The distance between the outer points, $S^{\prime}$ : Th distance side of the point 2.

Balance of the swing above can be used as a modality of two opposing nature or circumstances, large-small, healthy-ill, high-low, rich-poor, strong-weak, happy-sad, optimistic-pessimistic, satisfieddisappointed, stabil- unstable, fast-slow, hard-weak, sweet-bitter, and others. If the state at one pole of love, then penyeimbangnya grief, healthy penyeimbangnya sick, and so on. If the state at one pole is happy, then the balancing state is sad, healthy with sick, and so on. It is necessary to find the balance point of two opposing circumstances, so that people will not easily ngresula or complain, kaget or surprised, and gumun or wonder, but, tough, calm, strong, and fair in experiencing any circumstances. Ngono ya ngono ning aja ngono, a Javanese idiom, it means that we have to be always act fair and proper, and not to be overreacting, or sak madya. Urip sak madya means to live our life based on its proportion and balance, not to be too ambisious. Another Javanese idiom to illustrate this is aja rumangsa bisa ning bisoa rumangsa. It means that there is no truth, goodness, excellence, strength, greatness, beauty, and absolute beauty. Another one is bener ning ora pener means that if something is true for one person, it does not mean that it is appropriate or suitable for another person or group (Endraswara, 2010, p. 49-51).

A situation can sometimes be turned into another state. It is in contrast with the condition which is currently happening. Therefore, we need to be conscious and alert or éling lan waspada. Éling lan waspa$d a$ asks us to be cautious in every spoken word, act, and behavior in order to strong, stable, and not to be easily shaken when facing change in life. When people are not aware with the surrounding and also only depend on their aji mumpung, then, one day someone will receive the impact or punishment, ngundhuh wohing pakarti. Aji literally means weapon, while mumpung means when they are currently (Widodo, Suwadji, dkk, 2000, p. 526). Words following mumpung are: rich, powerful, beautiful, poor, low, etc. Aji mumpung means using the opportunity in order to get one's own benefit while one is rich, powerful, rich, beautiful, etc.

Supardi (2009, p. 93-95) says that Gusti Ora Saré, that God never sleeps, thus, sapa nandur bakal ngundhuh, whoever plants the trees, they will reap the harvest. Sapa nyilih mbalekake, whoever borrows someone's belonging, they have to return it. Sapa nggawe bakal nganggo, whoever makes they will uses it. Lastly, sapa sing mbibiti ala wahyune bakal sirna, that whoever does 
something evil, they will lose their luck. Besides the idioms mentioned above, there are still other idioms that illustrate the importance of having a balance life, such as: Sepi jroning rame means in a lonely state, there is a crowd; susah jroning bungah, inside the sadness there is happiness; peteng jroning padhang, in every darkness, there is a light; becik jroning ala, there is goodness in every bad things. The meaning behind the revious explanation is that in every condition there will be always another condition. These conditions can happened alternately at anytime. Balance is laras determinants. It is a wonderful, deep, and thorough sense of intrinsic. The schematic illustration of the conception of laras, along with the forming elements as well as the factors causing the manifestation to happen, is presented in the following scheme:

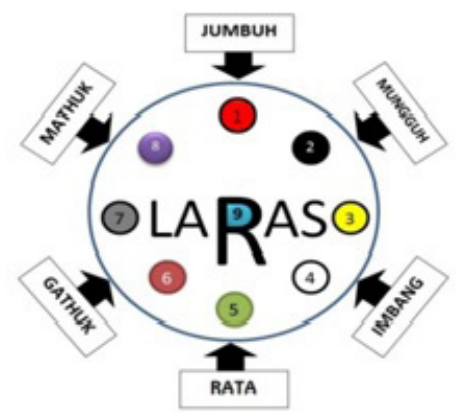

Figure 3. Laras, the aspects, and factors that cause its manifestations

Note: 1 enak, 2 kepenak, 3 éndah, 4 betah, 5 adhem, 6 ayem, 7 sengsem, 6 tentrem, 9 merdika

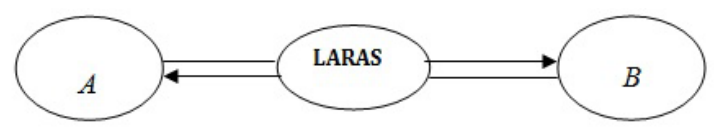

Figure 4. Laras in mutual attraction interaction between two elements

Note: A and B are elements of mutual attraction

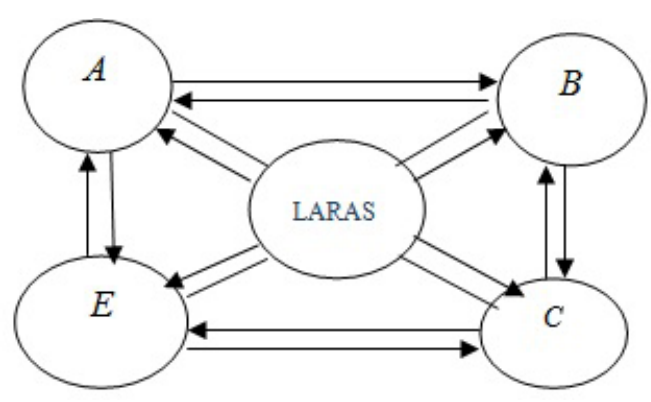

Figure 5. Laras in mutual attraction interaction between many elements

Note: A, B, C, and D are elements of mutual attraction

Common people often say that the sound of Javanese gending (songs) are less passionate and causing drowsiness. Statements are often given in negative connotation, that Javanese songs and sounds are no more than bedtime songs. However, for the people who love Javanese karawitan, they can feel the meaning of the songs and sounds wholeheartedly. The process of absorbing the meaning of the sounds and songs are best to be done while the eyes are closed. For the performers themselves, they often perform the Javanese karawitan while closing their eyes. They do it in order to feel the meaning behind the sounds. Further, in this state, they can concentrate to their performance better while attempting to also connect their instrument sounds with other aspects of the performance.

Buka is to start the gending performance by playing certain ricikan (instrument) or vocal. It needs to be responded by other ricikan (instruments) besed on the desired gending composition. If the response towards buka is not appropritate to the desired gending composition, then, the performance will be ruined. The worst part is when buka is never responded, therefore, gending will never be performed. Musical interaction between ricikan and vocal as well as vocal and ricikan in Javanese gending performance is conducted almost during the whole performance. Certain musical code which is given by kendang player needs to be responded by gong or ricikan 
balungan, and in another part needs to be responded by ricikan and vocal. Similarly, musical decoys from rebab needs to be responded by gendèr barung, the vocal musical code needs to be responded by bonang barung, etc. In order to make the musical interaction to run well, therefore, all performers need to have competence and full concentration along with the gending performance.

An offer to perform gending garap sirep, udhar, seseg, mandheg, suwuk, tomove on to another gending which is pioneered by kendang also needs to be responded by all ricikan based on their oen musical task. Because of the decoys are all musical, therefore, all of performers have to understand all the musical codes. By understanding and paying attention to each other while performing gending, thus, the musical interaction between performer will run well. If one of the performer does not pay their attention to the musical codes given, then, the musical interaction will be disturbed. Therefore, in performing gending, the performers have to give their full concentration to their own ricikan and vocal as well as to listen well to other plays in order to run the gending performance well. The concentration usually can be maintained while closing the eyes. This is when common people often misinterpret the situation by thinking that the performers are sleepy.

The performance of Javanese gending is conducted as if people are doing discussions with a considerable number of questions and answers. If the questions and answers in discussion are conducted verbally, then, in karawitan it employs the sounds of ricikan and vocal. If the questions in discussion are answered verbally by the presenters, then, the questions of musical code are answered musically by ricikan and vocal. Discussion can take place dynamically, beautifully, comfortably, happily, and fulfilling when the material quality and delivery of the questions and answers are done with mutual respect and appreciation, and so does with the gending performance. A beautiful musical dynamics will be built up when the musical in- teraction can take place properly. In order to create a series of qualified questions and answers, all participants or those who attended the discussion need to concentrate, pay attention, and respect each other. Similarly, in the gending performance, all performers must concentrate, pay attention, and give respect, so that the decoys and musical responses can run properly.

\section{CLOSING}

The above explanation is aiming at showing that gending performance applies the value of respect, harmonious, mutual cooperation, mad-sinamadandaya dinayan, and togetherness. Each ricikan and vocal with its own character and musical task composes the musical composition of Javanese karawitan, so that, the musical sound of gending is created. If one of ricikan or vocal is not presented, therefore, the beauty of the musical composition will be reduced. On the other hand, the more types of ricikan and vocal are involved, then, the composition sound of Javanese karawitan will be more beautiful as well. When the gending is performed by one outstanding performer, then, the sound of rebab will be heard beautifully, and so does with gendèr. However, it needs to be noted that the sound of rebab and gendèr are different. It will be impossible to produce the same sounds of the two very different instruments. The tone can be the same, but the sound colours are different. Differences in karawitan are intentionally created in order to establish musical conformity. If natural plurality and Nusantara culture are assembled as in the musical composition of Javanese karawitan, then, the beauty of its composition will be amazingly beautiful, or in another word, laras.

\section{REFERENCE}

Backer, Judith. (1980). Traditional Music in Modern Java. Hawai:The University of Hawai.

Benamou, Marc. (1998). Rasain Javanese Musical Aesthetics. Dissertation. 
Ann Arbor: UMI Company, The University of Michigan.

Bintarto, R. (1980). Gotong-Royong: Suatu Karakteristik Bangsa Indonesia. Surabaya: Bina Ilmu.

Brinner, Benjamin. (1995). Knowing Music Making Music Javanese Gamelan and The Theory of Musical Competence and Interaction. Chicago: The University of Chicago Press.

De Graaf \& Pigeaud.(2001). Kerajaan IslamPertama di Jawa, Tinjauan Sejarah Politik Abad XV dan XVI. Yogyakarta: Pustaka Pelajar.

Danandjaya, James. (1997). Folklor Indonesia. Jakarta: Pustaka Utama Grafiti.

Echols, John M \& Shadily, Hasan. (2010). Kamus Inggris Indonesia, An English-Indonesian Dictionary. Jakarta: Gramedia Pustaka Utama.

Endraswara, Suwardi. (2010). Falsafah Hidup Jawa, Menggali Mutiara Kebijakan dari Intisari Filsafat Kejawen. Yogyakarta: Cakrawala.

Geertz, Cliffort. (1992). Tafsir Kebudayaan. Yogyakarta: Kanisius.

Harjito, Priadi Dwi. (2001). Kebinekaan Laras, Keserupaan Laras, dan Metode

Penetapannya. Laporan Penelitian. Bandung: STSI Bandung.

Hastanto, Sri. (1985). The Concept of Pathêt in Central Javanese Gamelan Music. London: Universitas Durham.

Hastanto, Sri. (2009a). Konsep Pathêt dalam Karawitan Jawa. Surakarta: PPS ISI Surakarta \&ISI Surakarta Press.

Hastanto, Sri. (2009b). Penelitian Pengertian Konsep Embat dalam Karawitan Jawa. Makalah. Surakarta: ISI Surakarta.

Kartomi, Margaret J. (1990). On Concepts and Classifications of Misical Instruments. London:The University of Chicago Press.

Kayam, Umar.(1987). Keselarasan dan Kebersamaan: Suatu Penjelajahan Awal. Prisma, 16(3), 251-261.

Koentjaraningrat. (1990). Pengantar Ilmu Antropologi. Jakarta: Aksara Baru.

Koentjaraningrat. ( (1994). Kebudayaan Jawa. Jakarta: Balai Pustaka.

Kusnadi. (2006). Melodi dan Lirik Lagu
Campursari Ciptaan Manthous. Imaji Jurnal Seni dan Pendidikan Seni, 4(1), 109-123.

Liliweri, Alo. (2009). Makna Budaya dalam Komunikasi Antar Budaya. Yogyakarta: LkiS.

Lombard, Denys. (1996). Nusa Jawa: Silang Budaya (Jilid I). Jakarta: Gramedia.

Martopangrawit. (1975). Pengetahuan Karawitan. Surakarta: ASKI.

Rustopo. (2000). Bangun Jatuh Industri Rekaman (musik) Gending Karawitan Jawa. Jurnal Ilmu dan Seni, 2(2), 163-170.

Palgunadi, Bram. (2002). Serat Kandha Karawitan Jawi. Bandung: ITB.

Perlman, Marc. (1993). Unplayed Melodies Music Theory in Post Colonial Java. Dissertation. Wesleyen: Wesleyen University.

Santosa. (2001). Constructing Images in Javanese Gamelan Performance:

Comunicative Aspects among Musicians and Audiences in Villages

Comunities. Dissertation. Berkeley: University of California.

Santosa. (2011). Komunikasi Seni: Aplikasi dalam Pertunjukan Gamelan. Surakarta: ISI Surakarta Press.

Suharto, Ben. (1992). Pandangan Seni Tari terhadap Konsep Dasar Kenegaraan Pancasila

tentang Nilai Serasi, Selaras, dan Seimbang. Pidato Ilmiah Diesnatalis ke-8 Institut Seni Indonesia Yogyakarta. Yogyakarta:ISI Yogyakarta.

Sujamto. (1992). Reorientasi dan Revitalisasi Pandangan Hidup Jawa. Semarang: Dahara Prize.

Sumarsam. (1992). Historical Contexts and Theories of Javanese Music. Dissertation. Cornell: Cornell University.

Sumarsam. (2003). Gamelan, Interaksi Budaya dan Perkembangan Musikal di Jawa. Yogyakarta: Pustaka Pelajar.

Supanggah, (Ed.,). (1988). Dibuang Sayang, Lagu dan Gerongan Gending-gending Gaya Surakarta. Surakarta: ASKI Surakarta.

Supanggah, R. (2002). Bothekan Karawitan I. Jakarta: MSPI. 
Supanggah, R (2009). Bothekan Karawitan II: Garap. Surakarta: PPS ISI Surakarta \& ISI Surakarta Press.

Supardi. (2009). Gusti Ora Sare, 90 Mutiara Nilai Kearifan Budaya Jawa. Yogyakarta: Adiwacana.

Susena, Franz Magnis. (2003). Etika Jawa sebuah Analisa Falsafi tentang Kebijaksanaan Hidup Orang Jawa. Jakarta: Gramedia Pustaka Utama.

Sutton, R.A. (1991). Tradition of Gamelan Music in Java. Cambridge: Cambridge University Press.

Suwardi, A.L. (2000). Teknik Tabuhan dan Tutupan Gender. Surakarta: STSI.

Syafie, Inu Kencana. (2011). Teori Keseim- bangan. Jakarta: Rineka Cipta.

Walton, Susan Pratt. (1996). Heavently Nymphs and Eartly Delight: Javanese

Famale Singer, Their Music and Their Lives. Dissertation. Michigen: UMI.

Widada, Suwadji, \& Sukardi. (2001), Kamus Basa Jawa (Bausastra Jawa), Kanisius,Yogyakarta.

Widodo. (2010). Lelagon Dolanan Anak dan Pendidikan Karakter. Harmonia, 10(2), 170-183.

Winter \& Ranggawarsita. (1994). Kamus Kawi-Jawa. Yogyakarta: Gadjah Mada University Press.

Zoetmulder P.J. (2000). Kamus Jawa KunaIndonesia. Jakarta: Gramedia. 